\title{
Allegations of Corporate Human Rights Abuse in Latin America, 2000-2014: Insights from a new dataset
}

\begin{abstract}
:
This article presents a new dataset of allegations of corporate human rights abuse in Latin America from 2000-2014. The dataset responds to growing interest in the role of businesses in human rights violations, accountability processes for corporate abuses, and possible remedies for victims. It is the first dataset of its kind that offers a tool for analyzing five types of allegations of corporate human rights abuse (physical violence, development and poverty, health, environment, and labor) and judicial or non-judicial remedy mechanisms associated with each allegation. Initial analysis of the data show results that defy assumptions in the existing literature regarding which sectors are most likely to be targeted in allegations of abuse, who makes claims against companies, and the outcomes of those claims for victims of abuse.
\end{abstract}

\section{Key Words:}

Business ethics, human rights, remedy, non-judicial remedy, corporate social responsibility

Laura Bernal-Bermudez

DPhil Candidate

University of Oxford

Tricia D. Olsen

Assistant Professor

University of Denver

Leigh A. Payne

Professor

University of Oxford 


\section{Introduction $^{1}$}

Claims of corporate human rights abuse have emerged in every part of the world and so too have corresponding laws and voluntary agreements aimed at improving corporate behavior. Despite widespread interest among scholars, companies, states, international governmental and non-governmental bodies, and domestic human rights groups, no systematic cross-national study yet exists to track claims of corporate human rights abuse and the pursuit of remedy and accountability for those claims. The Corporate Human Rights Database - Latin America (CHRD-LA) seeks to fill that gap.

The CHRD-LA is comprised of allegations of corporate involvement in human rights abuses in 29 Latin American countries. The main source of that data is an online archive of claims hosted by the Business and Human Rights Resource Centre (BHRRC), from 2000 to $2014 .^{2}$ The database offers a full range of business sectors, firms, and country-contexts. The CHRD-LA includes multiple levels of data: the emergence of claims (grievances made), their institutionalization in formal processes (grievances heard), and their outcomes (grievances addressed).

The CHRD-LA is not alone in analyzing the role of businesses in human rights violations. There has been something of an explosion of literature on business and human rights in recent years. Not only has scholarship proliferated across management, business ethics, legal, sociology, and political science disciplines, ${ }^{3}$ new outlets-such as the Business and Human Rights Journal-have emerged to create a central resource for this research. The CHRD-LA, however, overcomes three main limitations in extant research. First, existing studies tend to focus on single firms, ${ }^{4}$ sets of advanced industrial

\footnotetext{
${ }^{1}$ We wish to acknowledge funding from the British Academy-Leverhulme, the University of Oxford Press John Fell Fund, and the University of Denver to support this project. In addition, we thank a team of coders for their work: Kathryn Babineau, Brandon Goldstein, Scott Leistiko, Dongjie Li, Suzanne Malcomm, Will Mateo, Megan Murobayashi, Louisa Murphy, Gabriel Pereira, Heather Randall, Aakash Saxena, Julia Schutt, and Julia Zulver. The project would not have been possible without this financial and coding support.

${ }^{2}$ We included all entries in the BHRRC website except for some NGO reports that did not constitute specific claims against companies. Where NGOs made claims, these appeared in media posts on the BHRRC and are therefore included in the CHRD-LA.

${ }^{3}$ The CHRD-LA team compiled a bibliography of these references that can be accessed on the database website: http://chrdproject.com/research.html.

${ }^{4}$ Reygadas, L. 2006. "Ch. 16: Corporate responsibility and social capital: the nexus dilemma in Mexican maquiladoras" in Sullivan (Ed.) Business and Human Rights: Dilemmas and Solutions (pp 207-218);
} 
countries, ${ }^{5}$ or small- $N$ comparisons of firms or business sectors. ${ }^{6}$ The CHRD-LA, in contrast, offers a large- $N$ comparative approach that includes 1,308 allegations for 916 firms with important variation on firm size, headquarter location, ownership structure, the profile of victims of these abuses, and the evolution and outcome of claims processes.

Second, although recent large- $N$ studies have begun to emerge, these studies tend to focus on large, publicly traded firms' participation in international voluntary principles (e.g. the Global Compact) rather than allegations of abuse of those principles. Bernhagen and Mitchell (2010), for example, examine the Forbes Global 2000 list of publicly traded firms in strong democracies (94 percent of the sample). They investigate a firm's commitment to the UN Global Compact by assessing internal measures, whether a firm has a human rights policy, and external measures, which they operationalize as a firm's inclusion on the Innovest Global 100 list of "most suitable corporations." The authors found that commitment to the UN Global Compact does generate a change in behavior; companies recognize that their commitments to human rights, environmental standards, and good governance have to be credible. These findings seem to verify theoretical arguments about firms" "reputational accountability."7 Mwangi and colleagues follow a similar research design by examining publicly traded firms in economically advanced democracies to analyze the impact of international voluntary principles on corporate behavior. ${ }^{8}$ To measure firm commitment to the UN Global Compact, the authors use the

Taylor, K. M. 2004. Thicker than blood: Holding Exxon Mobil liable for human rights violations committed abroad. Syracuse J. Int'l L. \& Com., 31, 273; Wheeler, D., Fabig, H. and Boele, R. (2002). 'Paradoxes and dilemmas for stakeholder responsive firms in the extractive industry: lessons from the case of Shell and the Ogoni'. Journal of Business Ethics, 39, 297-318.

${ }^{5}$ Chesterman, S. 2008. The Turn to Ethics: Disinvestment from Multinational Corporations for Human Rights Violations-The Case of Norway's Sovereign Wealth Fund. American University International Law Review, 23, 577-615; Hamann, R., Sinha, P., Kapfudzaruwa, F. \& Schild, C. 2009. Business and human rights in South Africa: An analysis of antecedents of human rights due diligence. Journal of Business Ethics, 87, 453-473; Santoro, M. A. 2000. Profits and principles: Global capitalism and human rights in China, Cornell University Press.

${ }^{6}$ Chandler, G. 1998. Oil companies and human rights. Business Ethics: A European Review, 7, 69-72; Drimmer, J. 2010. Human rights and the extractive industries: Litigation and compliance trends. The Journal of World Energy Law \& Business, 3, 121-139; Handelsman, S. 2003. Mining in Conflict Zones. In: Sullivan, R. (ed.) Business and Human Rights: Dilemmas and Solutions. Greenleaf Publishing; Woolfson, C. \& Beck, M. 2003. Corporate Social Responsibility failures in the oil industry. In: Sullivan., R. (Ed.) Business and Human Rights: Dilemmas and Solutions. Greenleaf Publishing.

${ }^{7}$ Bernhagen, Patrick and Neil J. Mitchell. 2010. "The Private Provision of Public Goods: Corporate Commitments and the United Nations Global Compact.” International Studies Quarterly 54(4):1175-87. Retrieved February 3, 2014 (http://doi.wiley.com/10.1111/j.1468-2478.2010.00631.x): 1185

${ }^{8}$ Mwangi, W., Rieth, L. \& Schmitz, H. P. 2013. Encouraging Greater Compliance: Local Networks and the 
company's engagement with regional and local networks (e.g., Global Reporting Initiative). They find that the Global Compact mechanisms for progressive implementation does not operate at the global level, but are more visible at the national level.

These examples demonstrate scholarly interest in companies' human rights behavior and the value placed in finding explanations for it. To date, however, scholarship has focused on the world's largest, publicly traded firms. ${ }^{9}$ The CHRD-LA project, in contrast, not only includes all allegations of human rights abuses for firms of any size or ownership structure, it also includes firm-level and state-level behavior and response to allegations, rather than using participation in voluntary principles as a proxy. The CHRD-LA thus allows scholars, practitioners, and policymakers to move beyond mere firm-level policy adoption to assess the practice by a range of firms that have (or have not) signed onto a variety of international or sector-specific principles. The focus of the CHRD-LA is thus the tracking of allegations of abuse and determining the responsiveness of governments and firms to those abuses in the form of remedy to victims.

Third, while some new studies include the developing world in their analysis of business and human rights, they often focus on corporate social responsibility (CSR), generally, rather than allegations of human rights abuse or engagement in remedy activity, specifically. Scholars at Darmstadt University of Technology and the Frankfurt Peace Research Institute, for example, studied business behavior in conflict zones between 2005 and 2009. They focused exclusively on contradictions in firms' CSR with efforts to establish security and strengthen their reputation in a context of permissive state attitudes and harsh public criticism. ${ }^{10}$ Lim and Tsutsui analyzed 99 countries in various

United Nations Global Compact. In: Risse, T., Ropp, S. C. \& Sikkink, K. (eds.) The Persistent Power of Human Rights Cambridge: Cambridge University Press.

${ }^{9}$ See also: Giuliani, E., \& Macchi, C. 2013. "Multinational corporations' economic and human rights impacts on developing countries: a review and research agenda." Cambridge Journal of Economics: http://doi.org/10.1093/cje/bet060

${ }^{10}$ Deitelhoff, Nicole et al. 2010. "Business in Zones of Conflict and Global Security Governance: What Has Been Learned and Where to from Here?" Pp. 202-26 in Corporate Security Responsibility? Corporate Governance Contributions to Peace and Security in Conflict Zones, edited by Nicole Deitelhoff and Klaus Dieter Wolf. New York: Palgrave Macmillan; Deitelhoff, Nicole and Klaus Dieter Wolf, eds. 2010. Corporate Security Responsibility? Corporate Governance Contributions to Peace and Security in Zones of Conflict. Basingstoke: Basingstoke : Palgrave Macmillan. 
world regions from 2000 to 2007 to examine their adoption of CSR policies. ${ }^{11}$ They found that one of the conditions that determined company CSR norm entrepreneurship was the strength of the host state, and the existence of reliable partners in the public sector. They find that when companies operate in conflict settings, efforts are directed to protecting their staff and facilities with few, if any, resources left for CSR initiatives.

These studies offer valuable insights into firms' CSR cultures and decisions in particular contexts, but they tell us very little about companies' responses to claims of corporate human rights violations and how they might be shaped by business cultures and violent contexts. In a sense, they leave victims out of the analysis of firms' human rights behavior. By focusing on allegations in one world region-Latin America- the CHRDLA offers the possibility of studying the human rights behavior of firms with and without CSR policies or programs. It further includes a range of country contexts: high levels of criminal and ongoing armed conflict (Colombia, El Salvador, Guatemala, Honduras, Venezuela); low levels of violence (Chile, Costa Rica, Bolivia, Peru); and medium levels of violence (Argentina, Panama, Mexico). It also includes a range of economic development contexts from the very poorest countries in the world (Haiti) to countries in which the richest business people in the world reside (Mexico and Brazil). The set of victims also include unionized and non-unionized, rural and urban workers in different sectors of the economy, indigenous and Afro-Latino peoples, women and men, represented by local, national, and international organizations.

The void that the CHRD-LA attempts to fill-the paucity of systematic information on business and human rights - is well recognized. John Ruggie, while serving as the UN Secretary General's Special Representative for Business and Human Rights, attempted to collect such data. His team produced a report that analyzed 320 allegations of corporate abuses between February 2005 and December 2007. ${ }^{12}$ Ruggie acknowledged the bias in the report. It relied on an unrepresentative collection of data that highlighted particularly emblematic allegations in priority industries or countries.

\footnotetext{
${ }^{11}$ Lim, A. \& Tsutsui, K. 2012. Globalization and Commitment in Corporate Social Responsibility CrossNational Analyses of Institutional and Political-Economy Effects. American Sociological Review, 77, 6998.

${ }^{12}$ Wright, Michael 2008. "Corporations and Human Rights: A Survey of the Scope and Patterns of Alleged Corporate-Related Human Rights Abuse". Cambridge: Corporate Social Responsibility Initiative, John F. Kennedy School of Government.
} 
Moreover, it provided descriptive data for only a short period of time. In sum, it was not representative enough to facilitate a broader understanding around whether firm-, national-, international-, or civil society-level factors influence the emergence of claims and when, how, and why they are heard and/or addressed.

The CHRD-LA seeks to fill this void and overcomes the limitations of previous studies by gathering and coding the data necessary to analyze allegations of corporate human rights violations and the pursuit of justice and remedies for such claims. The creation of an original, systematic, and comprehensive CHRD-LA provides a complete and usable database of claims from 2000 to 2014, from all countries in Latin America, and all sizes of public and private firms. Scholars can combine existing data on firms (i.e., market share; age; ownership structure; reputational index), the countries in which they operate (i.e., rule of law, authoritarian rule, civil conflict, and economic indicators), and global contexts (i.e., voluntary or industry initiatives adopted) to statistically analyze hypotheses derived from scholarly and public-policy theory. The database thus provides an important starting point for cross-national, multi-sector analysis of a range of firms with allegations of abuse. It further explores who has made claims (i.e., victims and their advocates) and how those claims have been addressed (i.e., through judicial, non-judicial, or no responses). The CHRD has limitations, discussed below. One of these is its limited global reach. The researchers plan to expand the database to eventually include all world regions and not only Latin America. They further plan to move beyond the claims made in the BHRRC archive to include a more complete set of allegations.

\section{Data Collection and Gaps}

The sample for the CHRD-LA is drawn from the claims included in the BHRRC. The BHRRC is considered the most comprehensive archive of newspaper articles and government, non-governmental organization, and business reports on business and human rights. From this collection, the CHRD-LA coded 1,308 claims in 29 Latin American countries from the BHRRC archive's origin in 2000 to 2014. While other studies have relied on the BHRRC, they either include a very limited timeframe or only Western, publicly traded firms and do not supplement additional data collection from 
sources beyond those listed in the BHRRC. ${ }^{13}$ The CHRD-LA team, alternatively, supplemented, analyzed, and codified other publicly available news sources on claims and responses to them to complete the dataset. The research team relied heavily on wire services, local news reports, and company websites to facilitate data collection for information not included in the BHRRC archive. ${ }^{14}$

Despite providing the most comprehensive source of data on business and human rights, the BHRRC recognizes certain limitations in its archive that thus affect the comprehensiveness of the CHRD-LA. Specifically, the BHRRC added country experts incrementally over time. New experts were not required to replicate the data collection process for claims made prior to their arrival. Thus some countries - such as Colombiahad experts collecting data since the creation of the BHRRC in 2000 and thus include more comprehensive coverage over time than those-such as Brazil-that acquired country experts only in the last several years. In addition, better global media coverage, investigative journalism, and freedom of expression render more information on allegations in some countries than in other countries that lack the same media standards. Finally, as with all media-based datasets, larger firms and abuses of internationally linked groups of victims tend to receive greater media attention and are thus more likely to be included in the BHRRC than claims against smaller companies in more isolated communities.

To determine the seriousness of the gaps in information, the CHRD-LA team compared the BHRRC's coverage against other sources. Replicating the BHRRC archive for two countries (Colombia and Peru), it found that the BHRRC included approximately 85 percent of all claims found through systematic online searches. Given the longstanding presence of Colombian researchers for the BHRRC, the assessment did not reveal a consistent pattern of missing cases. In Peru, however, the CHRD-LA team found that local sources, particularly the Defensoria del Pueblo (Human Rights Ombuds Office), included more coverage of claims against small and medium domestic firms. This is likely explained by the lack of visibility of these claims of alleged abuse in the

\footnotetext{
13 Wright, Michael 2008. "Corporations and Human Rights: A Survey of the Scope and Patterns of Alleged Corporate-Related Human Rights Abuse”. Cambridge: Corporate Social Responsibility Initiative, John F. Kennedy School of Government.

${ }^{14} \mathrm{We}$ conducted a Google Search for additional information, trying a variety of search terms to find additional information, but did not go past the second page of the Google search results.
} 
international coverage documented by the BHRRC. Recognizing the reporting inconsistency across countries and within countries, future phases of the CHRD-LA will rely on additional, local data sources in countries, particularly those that have received less coverage in the past fifteen years. Data analysis, moreover, should consider including fixed effects or controlling for country- or firm-specific characteristics that may have influenced reporting to ensure findings are robust. Even with these limitations, the CHRD-LA still provides a fuller set of allegations of company abuse than any other data set. The range of claims included provides a representative sample of corporate human rights abuse in a variety of contexts.

\section{Coded Terms and Concepts}

Debates over the definition of key terms and concepts in social science in general, and in the field of business and human rights in particular, require careful discussion of how they are established and operationalized in the CHRD-LA. These include how the CHRD-LA defines: corporation, human rights, allegation, abuse, and remedy. In addition, the sample and countries included in the CHRD-LA requires explanation. As described below, the process was precise enough for careful coding, but broad enough to serve scholars, practitioners, and policymakers interested in knowing more about specific types of violations, industry sectors, civil society actors, or types of states.

Corporation. For the CHRD-LA, the term corporation is synonymous with "business," "firm," or "company." It is defined as the group of individuals who legally engage in commerce with the goal of making a profit. Thus a corporation may be public, private, state-owned, or a joint enterprise.

In addition to including the specific company and parent company name, the CHRD-LA also tracks the sector and subsector of business. The project includes 27 industry sectors (e.g., agricultural, natural resources, consumer) that are listed in the Appendix, as well as a larger set of subsectors.

Allegation. Each allegation of corporate abuse made to the BHRRC appears as a corporate abuse claim (CAC). A CAC is defined as an instance in which a group and/or individual claims a company committed a human rights abuse. In addition to assigning a 
unique CAC identification number, the CHRD-LA also includes the date in which the allegation first appears, and who made the allegation (e.g., community members, national or international non-governmental organization, company employee(s), government agency, international governmental organization, media, religious organization, academic organization or research center).

Corporate Human Rights Violation. There is a tension in the business and human rights subfield around the degree to which non-state business actors can commit human rights abuses. On one side of the debate are those who claim that only states, and not businesses, are subjects of international human rights law; businesses therefore cannot be said to violate human rights norms. ${ }^{15}$ Another argument holds that members of the business community have been held accountable for human rights violations employing customary international law, such as the "industrialist cases" in the Nuremberg trials or cases brought under the Alien Torts Claims Statute in U.S. courts. ${ }^{16}$ Notwithstanding this ongoing legal debate, the BHRRC archive demonstrates that businesses are frequently and increasingly accused of engaging in gross human rights violations. Corporate human rights violations have not necessarily increased in recent years, but attention to them has increased along with awareness of companies' growing economic and political power domestically and globally, their expanding spheres of influence, and the complexity of the structures that they use to operate (involving parent companies, several layers of subsidiaries and corporate groups). The heightened role companies play in all aspects of individuals' lives, both in the public and the private sphere (e.g. they provide private security and surveillance, manage prisons, monitor elections, and provide water and sanitation) also explains the attention to their human rights records.

Without ignoring the complex nature of business and human rights and the unsettled nature of international human rights law in this domain, the CHRD-LA uses the BHRRC's designation of corporate human rights abuse. Information is coded on the relationship of the abuse to the company and the state. For example, data include whether the state assisted in the violation, committed the violation, acknowledged the violation

\footnotetext{
${ }^{15}$ See discussion about the legal impossibility argument in Clapham, Andrew. 2006. Human Rights Obligations of Non-State Actors. Oxford: Oxford University Press: 35-41.

${ }^{16}$ Schrempf-Stirling, J., \& Wettstein, F. (2015). Beyond Guilty Verdicts: Human Rights Litigation and its Impact on Corporations' Human Rights Policies. Journal of Business Ethics, 1-18.
} 
but without any official response to it, failed to acknowledge the violation, sought redress through trial, settlement, or restitution and compensation, or if the state had no involvement in the event. A brief narrative description of the role of the state in the violation is included along with the coded data. The CHRD-LA further designates the degree of company involvement in the abuse, such as whether it was direct or indirect and if the violation involved other companies. Rather than promote a single interpretation of businesses' human rights responsibilities, the CHRD-LA identifies when, where, and what types of claims have been made against companies for such abuses and the connection between the company and the state in these alleged abuses.

For each allegation a narrative description of the abuse is included that identifies the accused company name, who reported the abuse, the type of primary violation and related abuses, affected parties, recommended or achieved resolution and redress, and the source of the information. All of this information about the alleged abuse is also coded. In the CHRD-LA, each allegation falls into one of the BHRRC categories below:

- Physical Integrity: including murder, disappearance, kidnapping and illegal detention, torture;

- Development and Poverty: such as access to basic needs, development of local economy, exploitation of land, license to operate, freedom of association/expression;

- Environment: specifically, water, air, land contamination; deforestation; destruction of natural resources;

- Labor: comprising forced labor, child labor, right to unionize, substandard working conditions; and

- Health: including health concerns due to corporate activity or access to medicine.

Additional information included in the CHRD-LA are the dates the violation began and, if available, ended. It also lists who was affected by the violation (e.g., workers, local communities, or general public).

Corporate Response. The CHRD-LA records the allegations of corporate human rights violations. To avoid slander or calumny charges, the BHRRC allows companies an 
opportunity to respond to the allegations made in its archive. Company responsesestimated by the BHRRC to be approximately 75 percent of cases-are included along with the claim of abuse, ${ }^{17}$ yet the CHRD-LA includes far fewer responses from companies than the figure estimated by the BHRRC. According to the BHRRC, the low level of responses in the Latin American cases coded in the BHRRC may be because the BHRRC only requests response to violations of a certain magnitude and the CHRD-LA includes a full range of violations. Where such responses appeared in the BHRRC archive or in any other publicly-available source, the CHRD-LA includes data on who responded on behalf of the company (e.g., local branch, national headquarters, international headquarters or parent company) and that individual's position in the business (CEO/President, Company legal representative, member of the board of directors, public relations spokesperson, human resources or corporate services). The CHRD-LA also records the date and a narrative description of the response. The CHRD-LA categorizes the following types of responses: denial (subcategorized in terms of exaggeration, exclusion, or incorrect reporting of facts), acknowledgment, justification of action, apology, and plan for change.

Remedy. Rather than only focusing on allegations of abuse, the CHRD-LA also includes state and firm behavior to remedy such claims-judicial and non-judicial remedy mechanisms, respectively. This component of the database allows researchers to address questions of corporate accountability in judicial institutions and when firms are willing to engage in non-judicial remedy mechanisms with key stakeholders. With regard to legal action, the dataset includes which party initiated the action, on what date, the type of action (civil or criminal), in what court the claim was filed, when and to what effect. In particular, the CHRD-LA tracks whether and what type of damages were awarded. Other types of judicial action include out of court settlement, dismissal, and appeal. For criminal cases plea-bargaining is also recorded. Judicial outcomes in terms of acquittal or sentencing are also recorded. Non-judicial actions, initiated by any party, are also included and recorded in a similar fashion, including the date, type, person or organization initiating, and outcome.

\footnotetext{
${ }^{17}$ See https://business-humanrights.org/en/company-response-rates
} 
Latin American Countries. There are a number of different ways to define Latin America and the CHRD-LA has chosen the most comprehensive so as to facilitate studying a variety of economic development and institutional contexts. It includes Mexico and Central America, South America, and the Caribbean. The regional scope of the CHRD-LA thus includes 29 countries. The region includes great diversity for assessing business and human rights. It includes the poorest countries in the world (Haiti) and globally competitive ones (Brazil, Chile, and Mexico). The range of investment in the region-from high yield extractives such as oil and mining to consumer goods and tourism - is also vast. In addition, the region includes stable and peaceful democracies (such as Costa Rica) to those seeking to achieve peace (Colombia), political instability (Venezuela), or dealing with high levels of violent crime (El Salvador, Guatemala, and Honduras).

\section{Allegations of Corporate Human Rights Abuse in Latin America}

Most research on business and human rights focuses on emblematic cases, leading to the conclusion that allegations of corporate human rights abuse are only about physical violence. Our data, however, uncover a different story. We find that allegations of corporate human rights abuse span all five categories outlined above. While those allegations involving physical integrity abuse are the most common (35 percent), we also find substantial evidence of allegations about the environment (26 percent), labor (16 percent), development (14 percent) and health ( 9 percent). 


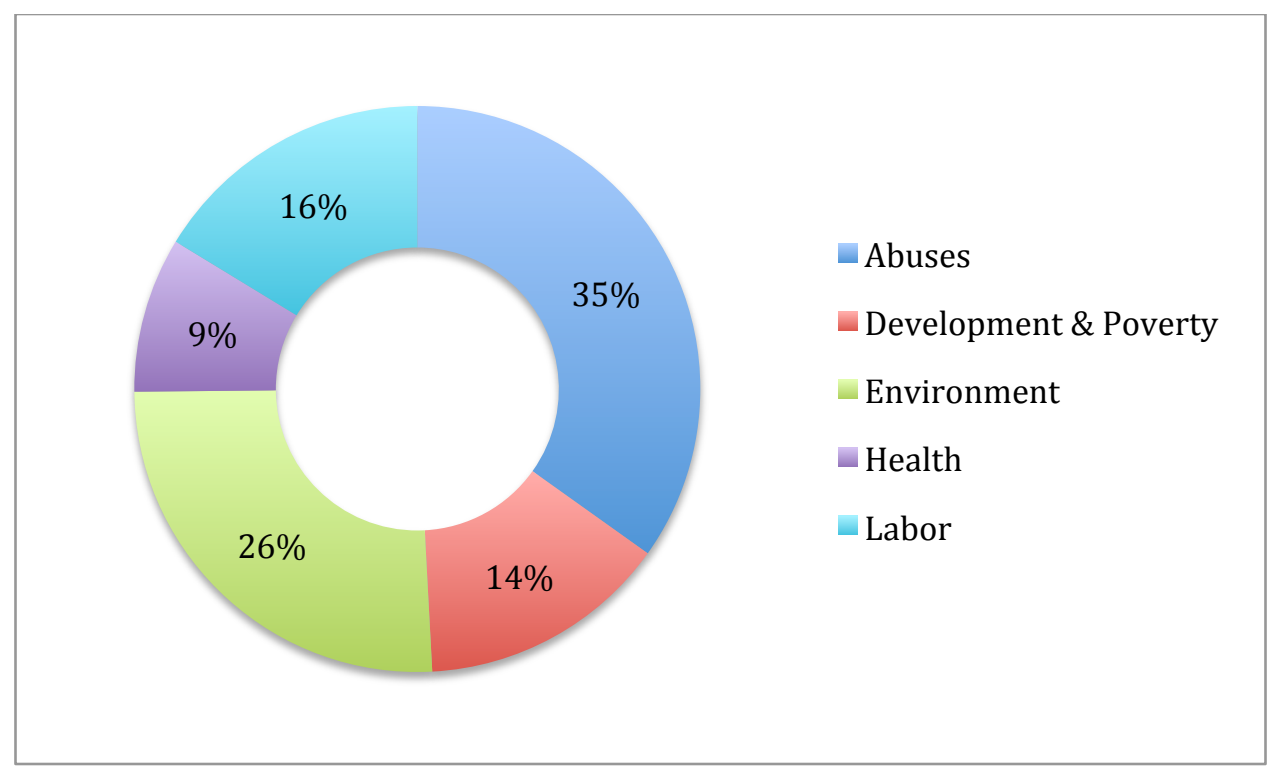

Figure 1: CHRD-LA, by Allegation Type

Physical integrity abuses constitute the most frequent allegation (Figure 1). The CHRD-LA indicates that beyond deaths, beatings and human trafficking are the most common allegations of abuse. With regard to environmental allegations, concerns of water pollution and the destruction of natural resources (e.g., deforestation or infringing on wildlife ecosystems) are the most common. Labor allegations are generally about the denial of freedom of association and poor labor standards. Those allegations that fall into the development category are primarily about being denied the right to prior consultation and conflicts with indigenous populations over land usage. Finally, health allegations include concerns about the surrounding community's health, given the operation and/or activity of the firm. 


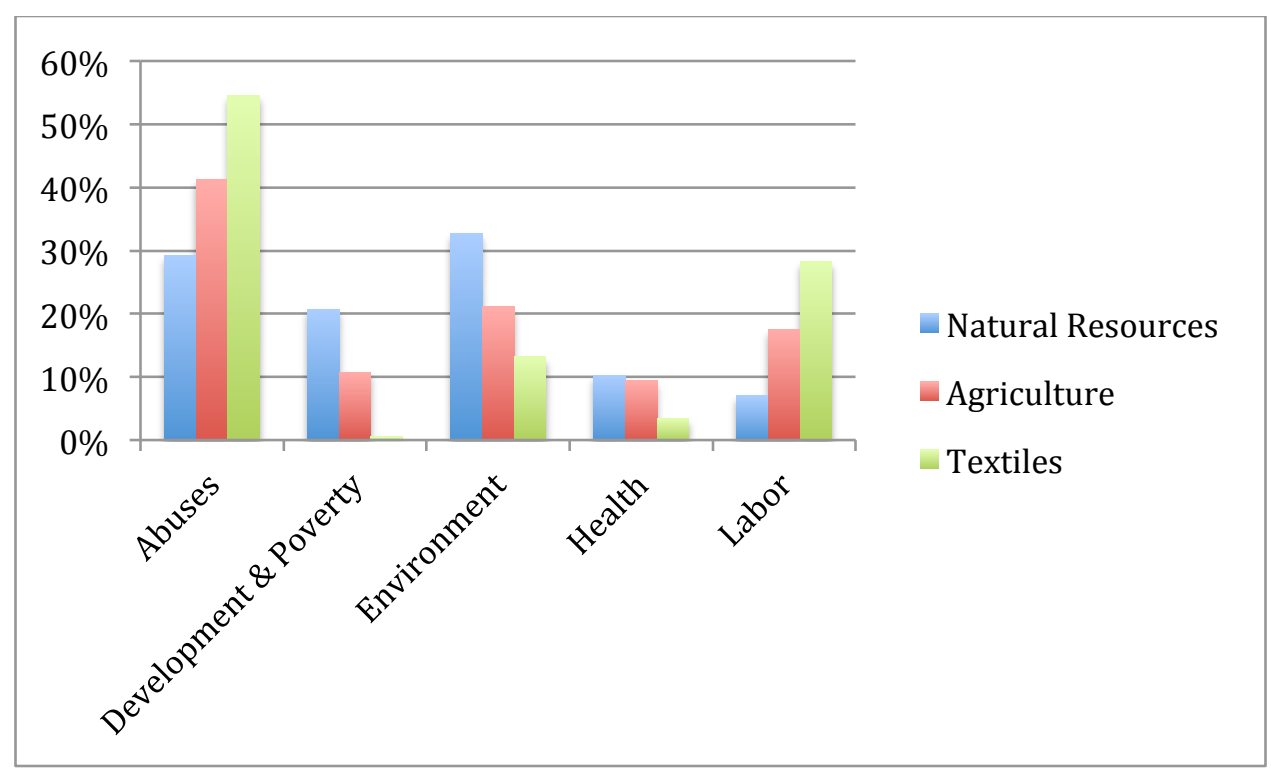

Figure 2: CHRD-LA, by Allegation Type and Industry

Our data also shed light on interesting variation across industry sectors (Figure 2). While the CHRD-LA spans over twenty sectors, three sectors account for the bulk of the allegations: natural resources (36 percent or 469 allegations); agriculture (17 percent or 227 allegations); and apparel and textiles (16 percent or 206 allegations). Within those sectors, we observe that textiles account for the majority of allegations within the abuse category, followed by agriculture and natural resources (see Figure 2, far left). While natural resources still have the largest number of violations, by count, the proportion of physical integrity violations are lower than other industries, specifically apparel and textiles. This finding challenges the tendency in the literature to focus on the extractive industry as the source of allegations of physical integrity abuse and to overlook the great variety of claims in other sectors. ${ }^{18}$

\footnotetext{
${ }^{18}$ Bebbington, A. 2010. "Extractive industries and stunted states: conflict, responsibility and institutional change in the Andes." Corporate social responsibility: Comparative critiques, 97-116; Arellano-Yanguas, J. 2011. "Aggravating the resource curse: Decentralisation, mining and conflict in Peru." The Journal of Development Studies, 47(4), 617-638; Bebbington, A. (Ed.). 2011. Social conflict, economic development and the extractive industry: evidence from South America (Vol. 9). Routledge; Sawyer, S. 2004. Crude chronicles: indigenous politics, multinational oil, and neoliberalism in Ecuador. Duke University Press.
} 


\begin{tabular}{lrrr}
\hline Abuse & 43,531 & 11.09 & $46,078,544$ \\
$\begin{array}{l}\text { Development \& } \\
\text { Poverty }\end{array}$ & 21,869 & 20.07 & $72,176,855$ \\
Environment & & & \\
Health & 43,429 & 13.60 & $45,064,018$ \\
Labor & 25,616 & 14.34 & $28,445,787$ \\
Total Averages & 75,058 & 9.96 & $14,614,023$ \\
\hline
\end{tabular}

Table 1: Firm-Level Average Data, by Allegation Type

Combining the CHRD-LA with firm-level data also illustrates interesting trends about firm characteristics and allegations. ${ }^{19}$ While some literature suggests victims are likely to make claims against large firms, ${ }^{20}$ our findings show allegations are made against a wide range of firms. Allegations of abuse are made to relatively mid-sized, profitable firms. Development and poverty claims are made to more profitable firms and those that have relatively few employees, but high levels of assets. This is likely because many extractive companies receive many development and poverty claims. Environmental claims, like abuse claims, are made against mid-sized, profitable firms. Those firms alleged to have committed health abuses are relatively small in terms of employees and assets, but tend to be more profitable than their peers. Finally, labor claims - perhaps due to their concentration in textiles - are made against firms with a large number of employees and relatively low profit margins.

\footnotetext{
${ }^{19}$ These data were extracted from the Bureau van Dijk (BvD) dataset, which is the most comprehensive dataset of public and privately held firms. Of the 1,308 allegations in the CHRD-LA, 1,170 are included in BvD. However, BvD includes data for the last decade (2005-2015) and, unfortunately, only has financial data for fewer than half of the allegations $(\mathrm{N}=627$ for employees; $\mathrm{N}=497$ for profit margin; $\mathrm{N}=550$ for assets).

${ }^{20}$ King, B. G. (2008). A Political Mediation Model of Corporate Response to Social Movement Activism. Administrative Science Quarterly, 53(3), 395-421; King, Brayden G. 2011. The tactical disruptiveness of social movements: Sources of market and mediated disruption in corporate boycotts. Social Problems 58(4): 491-517; King, Brayden G. and Mary-Hunter McDonnell. 2015. Good firms, good targets: The relationship between corporate social responsibility, reputation, and activist targeting. Corporate social responsibility in a globalizing world: Toward effective global CSR frameworks, edited by Kiyoteru Tsutsui and Alwayn Lim. New York: Cambridge University Press.
} 


\begin{tabular}{ll}
\hline Group Reporting Claim & Percentage of Total Allegations \\
\hline NGOs & 19.11 \\
\hline INGOs & 27.06 \\
Community groups & 9.71 \\
Employees & 2.29 \\
Unions & 3.82 \\
Gov't representative & 10.01 \\
\hline Media outlets & 31.35 \\
\hline
\end{tabular}

Table 2: Groups Making Allegations

The CHRD-LA also includes information on which group or groups made the initial claim. Sometimes multiple groups make the initial claim, so the numbers above surpass one hundred, as coders were able to choose multiple answers. NGOs and INGOs make up a large share of the organizations that bring such allegations to light — nearly one in five claims are initially reported by a NGO while over one in four are initially reported by an INGO. Community groups or government representatives are involved in claimmaking in approximately one out of every ten allegations. If no group was mentioned or indicated, coders would note that media outlets reported the claim, originally. As such, the media served as the initial outlet for nearly one-third of the claims in the CHRD.

\section{Access to Remedy for Corporate Human Rights Abuse in Latin America}

Given that our sample includes all allegations of corporate human rights abuse, the CHRD-LA allows scholars and policymakers to gain a better understanding of when victims have access to remedy - that is, when allegations were institutionalized in formal or informal processes and addressed. 


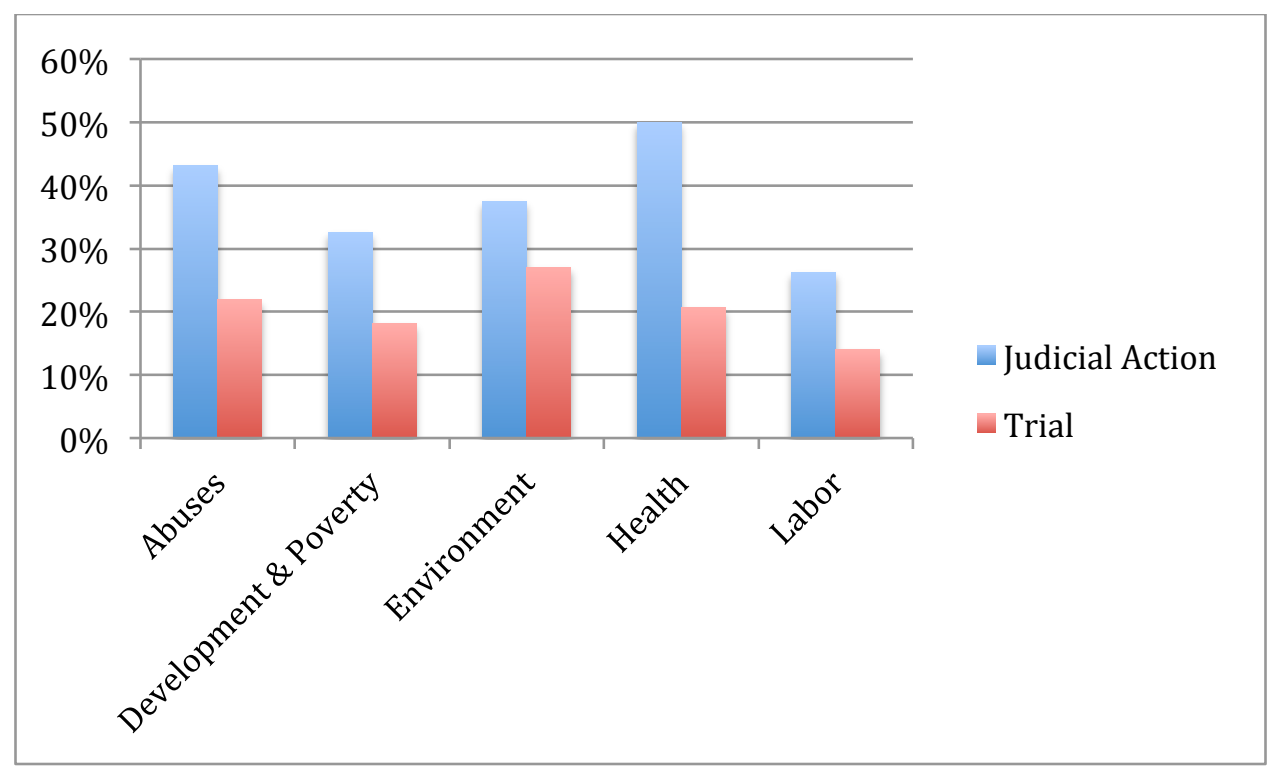

Figure 3: Judicial Action and Trials, by Allegation Type

The CHRD-LA includes data on any judicial action (Figure 3) taken as a result of the claim. Judicial action includes an investigation initiated by a governmental institution (ombudsman's office, truth commission, police, judicial, or legislative investigation) or trial activity (initiated, for example, but dismissed). As other scholars have noted, there is great variation in domestic courts in terms of their capacity or willingness to take on corporate human rights abuse. ${ }^{21}$ The unsettled nature of international human rights law with regard to business, and the focus instead on "voluntary principles" embodied in the UN's Guiding Principles (UNGPs), has produced a weak international enforcement mechanism and little normative pressure on domestic courts to hold companies accountable for abuses. $^{22}$

\footnotetext{
${ }^{21}$ van der Wilt H. 2013. Corporate criminal responsibility for international crimes: exploring the possibilities. Chin. J. Int. Law 12(1):43-77; Zerk J. 2014. Corporate Liability for Gross Human Rights Abuses: Towards a Fairer and More Effective System of Domestic Law Remedies. Geneva: UN High Comm. Hum. Rights

${ }^{22}$ Clapham A. 2000. The question of jurisdiction under international criminal law over legal persons: lessons from the Rome Conference on an international criminal court. In Liability of Multinational Corporations under International Law, ed. MT Kamminga, S Zia-Zarifi, pp. 139-95. The Hague, Neth.: Kluwer Law Int; Horrigan B. 2010. Corporate Social Responsibility in the 21st Century: Debates, Models and Practices across Government, Law and Business. Cheltenham, UK: Edward Elgar); Paul G \& Schönsteiner J. 2013. Transitional justice and the UN guiding principles on business and human rights. In Corporate Accountability in the Context of Transitional Justice, ed. S Michalowski, pp. 73-92. Abingdon, UK: Routledge; Weissbrodt D, Kruger M. 2005. Human rights responsibilities of businesses as non-state actors. In Non-State Actors and Human Rights, ed. P Alston, pp. 315-49. Oxford: Oxford Univ. Press).
} 
Nonetheless, the UNGPs do emphasize states' roles in the area of business and human rights, particularly in the advancement of the three normative principles to "respect, protect, and remedy." The CHRD-LA reflects this situation: only one in four of all allegations (38 percent or 498 allegations) involved any type of judicial action ranging from initial judicial investigation to trial and sentencing. We find that nearly one in five allegations, overall, go to trial. The frequency with which either judicial activity or a trial is initiated, however, varies by allegation. While judicial action is quite likely, relatively speaking, for allegations of abuse and health, it is more likely that a trial is initiated in environmental allegations, as indicated in Figure 3.

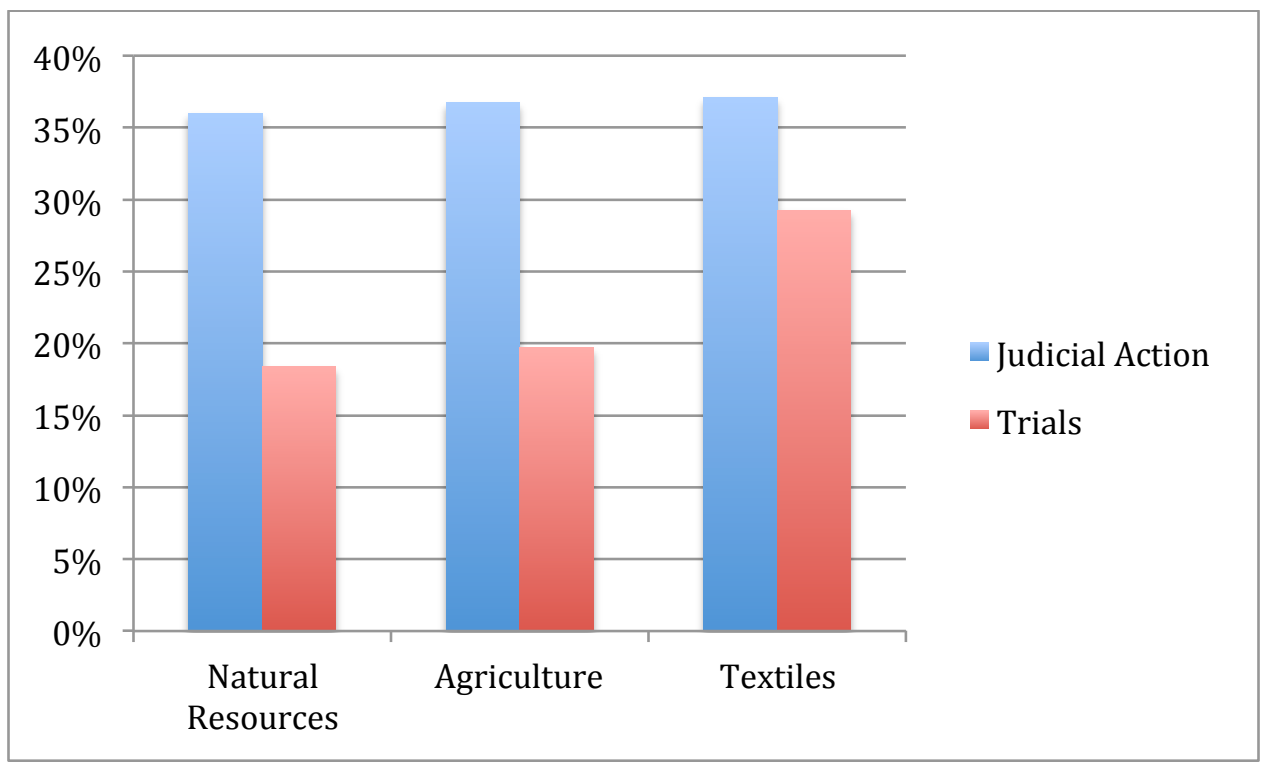

\section{Figure 4: Judicial Action and Trials, by Industry}

Approximately 35 percent of the allegations in the CHRD-LA are associated with some type of associated judicial activity. Figure 4 illustrates the variation across industries. While nearly one in five (18 percent) of those allegations in natural resources or agriculture are associated with a trial, that number jumps to nearly three in ten (29 percent) of the apparel and textiles sector. Judicial action, for all three sectors, occurs in approximately one-third of the allegations in these sectors. 


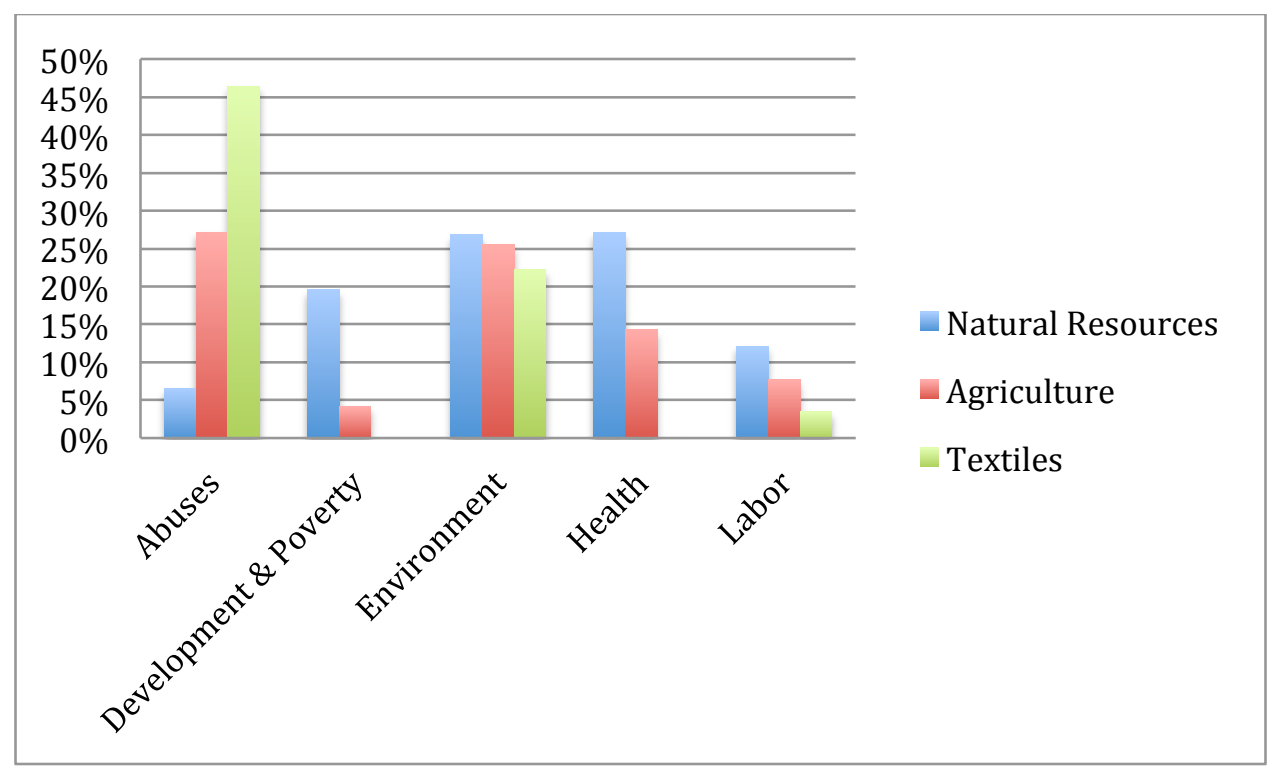

Figure 5: Trials, by Allegation Type and Industry

As we can see from Figure 5, it is clear that many of the allegations of abuse in the apparel and textiles industry are brought to trial. The CHRD-LA illustrate that although the natural resources sector is the target of the bulk of allegations of abuse, very few of those allegations go to trial. Instead, the data show that allegations of other violations are more frequently to go to trial. These trends suggest that more nuanced understanding of the evolution of claims reveal very different outcomes than expected. The high visibility of claims against mining and other natural resource companies has not yet rendered judicial outcomes. Judicial activity has been more likely in the apparel and textile sector, perhaps as a result of concerted civil society campaigns in this sector.

Figures 6-8, below, illustrate that those firms for which there is some type of trial activity tend to have fewer employees, are less profitable, and have fewer assets than their peers who have faced allegations of human rights abuse, but have not faced a formal trial. Figure 6, for example, illustrates that those firms that face trials and are found guilty or must pay damages are much smaller than their counterparts. While the difference is not as stark, these trends are also noted in firms' average profit margin (Figure 7) and average assets (Figure 8), as well. ${ }^{23}$

\footnotetext{
23 As noted in fn 18, firm-level data were extracted from the Bureau van Dijk (BvD) dataset, which is the most comprehensive dataset of public and privately held firms. Yet, of the 1,308 allegations in the CHRD-
} 


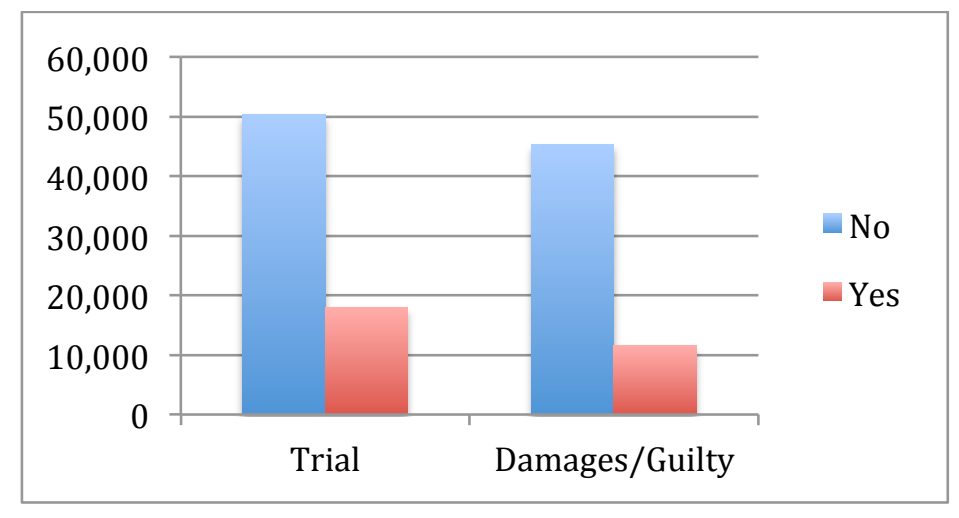

Figure 6: Trial Activity, by Average Employees

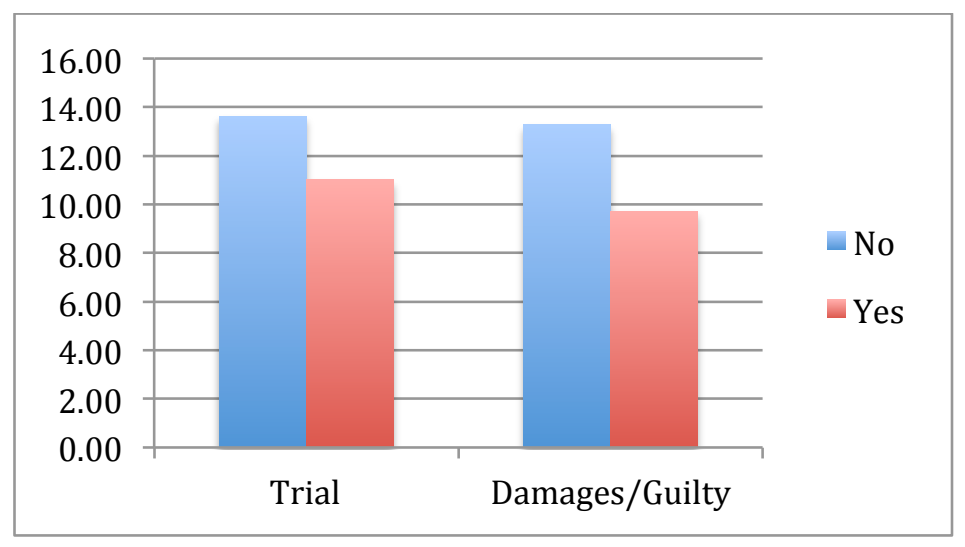

Figure 7: Trial Activity, by Average Profit Margin

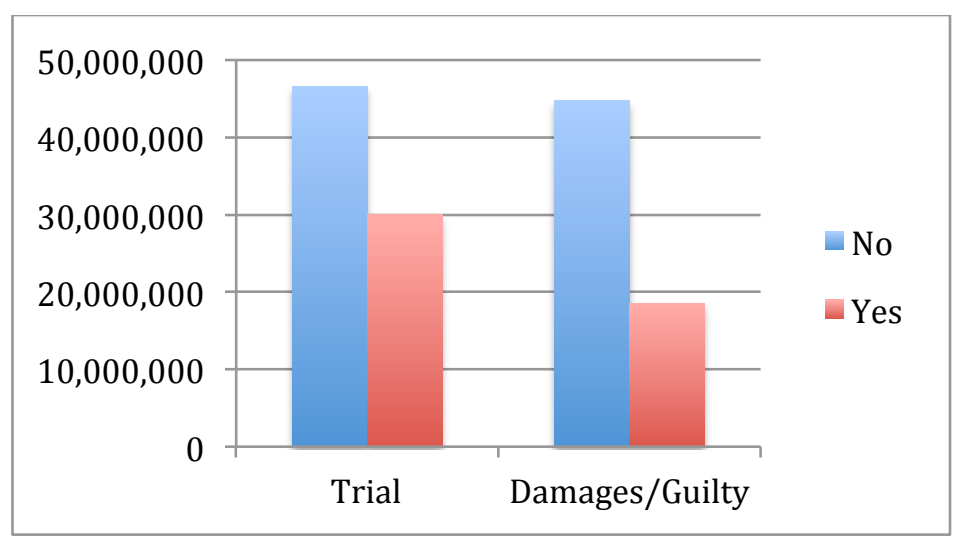

Figure 8: Trial Activity, by Average Assets

LA, 1,170 are included in BvD. And, further, BvD has financial data for fewer than half of the allegations ( $\mathrm{N}=627$ for employees; $\mathrm{N}=497$ for profit margin; $\mathrm{N}=550$ for assets). It is interesting, however, that we still see noteworthy differences, even with these limited data (which are likely skewed toward larger firms). 
The CHRD-LA allows researchers to also examine whether a firms' headquarters shapes trial activity or whether claims reach an outcome (e.g., criminal sentence, civil ruling). The CHRD-LA illustrates that trial activity is more likely against domestic firms - nearly one in four domestic firms face some type of trial activity (27 percent or 179 of 671 allegations) while just over one in ten foreign firms face trial activity (12 percent or 61 of 499 allegations). ${ }^{24}$ Interestingly, foreign firms from the region and based in a Latin American country (e.g., a Brazilian firm working in Argentina) face trial more often (19 percent or 10 of 53 allegations) than European (13 percent or 21 of 166 allegations) or North American (United States and Canada) companies operating in the region (11 percent or 28 of 255 allegations). Approximately half of all allegations in which a trial is initiated end in a verdict that awards damages or finds corporate actors guilty - regardless of the firm's headquarters location (90 of 179 for domestic firms and 27 of 61 for foreign firms). The only exception to this trend is the Latin American or Asian foreign firms, which have lower frequency of damages or guilty verdicts. ${ }^{25}$

The findings - that domestic firms are more likely to face trial-confirms assumptions about the difficulty of holding foreign or transnational corporations liable. Some of the obstacles result from practical considerations such as obtaining documents, seizing assets, or speaking to management located abroad. Certain legal mechanisms, such as forum non conveniens, also allow foreign companies to venue shop to avoid judicial action in more hostile courts. ${ }^{26}$ The CHRD-LA thus documents with empirical data the relative difficulty of holding foreign companies accountable.

\footnotetext{
${ }^{24}$ Note that the total number of allegations in this discussion is 1170 , rather than 1308 . Again, this is due to missing headquarters data from $\mathrm{BvD} /$ Orbis.

${ }^{25}$ Note that there were so few companies with headquarters in other regions of the world (e.g., Africa, Asia, the Middle East and Oceania) that those regions are not included in Table 3.

${ }^{26}$ Meeran, R. (2013). Access to remedy: the United Kingdom experience of MNC tort litigation for human rights violations. In S. Deva \& D. Bilchitz (Eds.), Human Rights Obligations of Business: Beyond the Corporate Responsibility to Respect? (pp. 378-402). Cambridge: Cambridge University Press; Skinner, G. (2014). Beyond Kiobel: Providing Access to Judicial Remedies for Violations of International Human Rights Norms by Transnational Business in a New (Post-Kiobel) World. Columbia Human Rights Law Review, 46(158).
} 


\begin{tabular}{lcc}
\hline & $\begin{array}{c}\text { Trial Activity (\% } \\
\text { of Allegations) }\end{array}$ & $\begin{array}{c}\text { Damages/Guilty } \\
\text { Verdict (\% of } \\
\text { Allegations) }\end{array}$ \\
\hline Domestic Firm & 27 & 13 \\
\hline Foreign Firm & 12 & 5 \\
Europe & 13 & 6 \\
LatAm & 19 & 6 \\
\hline NorthAm & 11 & 5 \\
\hline
\end{tabular}

Table 3: Trial Activity and Outcomes, by Firm Headquarters Location

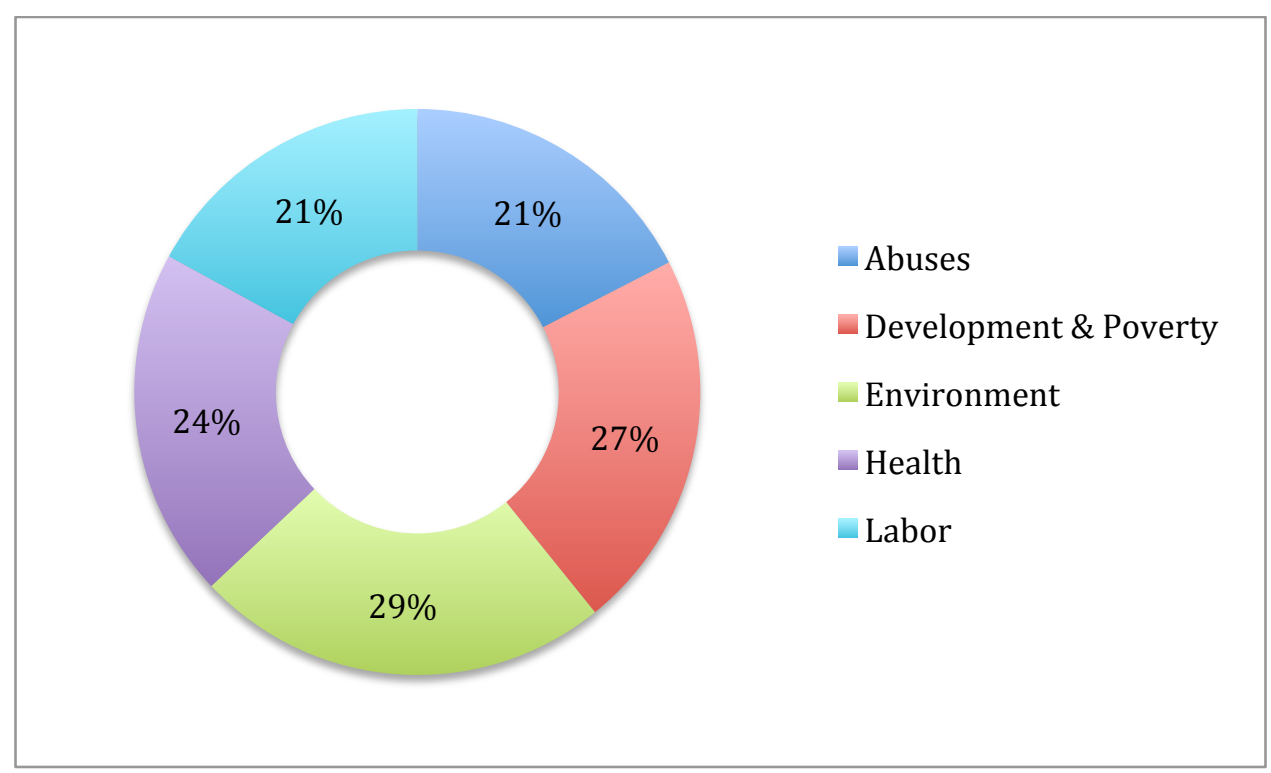

Figure 9: Non-Judicial Remedy, by Allegation Type

Finally, the third pillar of the UNGPs notes the importance of remedy and includes non-judicial remedy. Non-judicial remedy can include any type of alternative dispute resolution, such as multi-stakeholder initiatives, roundtables, third-party mediators or conciliation (Figure 6). Approximately one in four (24 percent) of the allegations in the CHRD-LA include some type of non-judicial remedy. This result is surprising given the nascent nature of the UNGPs and the assumed novelty of such nonjudicial remedy mechanisms. Non-judicial remedies, however, follow no discernible 
patterns across allegation types, but are instead used in all types of abuses in 21 to 29 percent of the outcomes.

In addition, it appears all types of firms employ or engage with non-judicial remedy mechanisms. Foreign firms, regardless of where they are headquartered, use nonjudicial remedy at about the same rate as domestic ones. One in four (24 percent or 164 of 671 allegations) allegations against domestic firms end in non-judicial remedy while that number drops only a bit (22 percent or 110 of 499 allegations) for firms headquartered abroad. Of foreign firms, those within the Latin American region are most likely (28 percent or 15 of 53 allegations) to use non-judicial remedy. But North American firms engaging in non-judicial remedy mechanisms follow close behind with a quarter of the allegations ( 25 percent or 65 of 255 allegations). European firms are less likely (17 percent 28 of 166 allegations), but not by much, to employ such mechanisms.

The size of the firm - measured in terms of profit margin and assets - does not distinguish the firms employing non-judicial remedy from those that do not. The profit margin for firms that use non-judicial remedy mechanisms is about equal to those that do not (13.62 and 13.70, respectively). This may indicate that profit or slack is not necessarily a top consideration when deciding to engage in such remedy mechanisms. Likewise, the average assets for those that do (approximately 36.8 million) and those that do not (46.2 million) are relatively close - especially compared to the differences we saw above regarding trial activity. If any distinguishing feature of size exists for those firms engaged in non-judicial remedies exists, it is in the number of employees: firms that use non-judicial remedy have about 20,000 more employees than those that do not $(61,649$ vs. 38,943). It may be that firms employing a larger number of employees recognize the potential for increasing levels of judicial actions against them and they attempt to offset such outcomes by pursing less costly non-judicial remedies.

\section{Conclusion and Future Areas of Research}

The descriptive statistics provided here suggest that the CHRD-LA, with its systematic data collection of all allegations of abuse in one world region, provides insights into previously untested assumptions in the existing literature. While some of that literature 
suggests that high profile companies in extractive industries might be targeted by internationally-linked human rights organizations, the CHRD-LA data do not entirely support such claims. Preliminary analysis confirms that international non-governmental organizations more frequently bring claims on behalf of victims than domestic organizations, but the media appears to be a stronger protagonist in making those claims visible internationally. In addition, textile and apparel sectors are more commonly accused of physical integrity violations than natural resource firms. Finally, domestic firms are more likely to face trial activity and verdicts than foreign companies. Moreover, large firms, measured in terms of the average number of employees, are more likely than smaller ones to engage in non-judicial forms of remedy.

Further analysis and data collection in other world regions is warranted to determine whether these trends are unique to Latin America or world-wide, whether there is a temporal dimension to these findings owing to anti-sweatshop campaigns in the textile and apparel industry, or whether there are other explanations for the challenges to existing assumptions. The value of the CHRD-LA and other types of large- $N$ comparative studies in tracking global trends regarding abuse is evident, even in the preliminary analysis.

Even without a cross-regional comparison, researchers in the CHRD-LA team have conducted specialized analysis of trends within countries, sectors, and contexts that have further challenged existing assumptions. A study of Peru (Babineau 2015) found that Global Compact signatories were just as likely as businesses who did not sign on to be accused of human rights violations; they were, moreover, equally unlikely to remedy violations. Pressure from the government—not voluntary principles—seemed to promote companies' positive human rights behavior. A study of Colombia (Bernal-Bermúdez 2016) also found few human rights behavioral differences among firms that signed onto voluntary principles compared with those that had not. Both statistical and qualitative case study analyses pointed to pressure from transnational advocacy networks for positive human rights outcomes. Summarizing these empirical findings, at best voluntary principles have done little to diffuse understanding of business obligations under international human rights law. At worst, they signal to businesses and states that these obligations are voluntary, thereby undermining efforts to strengthen global human rights 
protections. These findings would not be possible without the systematic and comprehensive data provided by the CHRD-LA. They further show that despite pessimism regarding victims' access to justice and remedy for corporate human rights abuses, there are certain models that have emerged that could be replicated in other contexts, even where corporations continue to amass significant global economic and political power.

Two of the CHRD-LA team members have expanded the data set to include global aspects of particular sectors of industry or types of abuses. One study extends the CHRD-LA to include extractive industries across Asia and Africa. Some scholars note that industry-specific initiatives, such as the Extractive Industry Transparency Initiative (EITI), may make firms easy targets for human rights allegations. The logic is that it is easier for activists to point out shortcomings for those firms that have publicly committed to specific standards. The study finds the opposite: those firms that comply with EITI requirements are less likely to face judicial activity. The insight from this study is that firms must meet certain standards to yield the benefits of certain voluntary initiatives and, as a result, are less vulnerable, rather than more, to judicial claims against them. ${ }^{27}$ The study further finds that country-level political economy factors are relevant. Firms are more likely to face judicial activity in countries with strong rule of law and, perhaps in a complementary fashion, are more likely to use non-judicial remedy in those countries with relatively weaker rule of law. Moreover, even when considering EITI membership, firms that face allegations in states that are heavily dependent on rents from oil/gas extraction are less likely to face judicial activity or trial. ${ }^{28}$ This study shows that both working within and moving beyond Latin America, the CHRD has the potential to identify the conditions and factors most likely to lead to accountability for allegations of human rights abuse.

A second project emerging from, and extending beyond, the CHRD-LA focuses on practical implications. Team members have developed from the CHRD-LA a Corporate Accountability and Transitional Justice (CATJ) advocacy tool to consider which judicial and non-judicial models have worked around the to address the needs of

\footnotetext{
${ }^{27}$ Olsen, Tricia D., Kathleen Rehbein, and Michelle Westermann-Behaylo. Working Paper, "State regulation versus corporate self-governance: Holding corporations accountable for human rights abuses."

${ }^{28}$ Olsen, Tricia D. Book Manuscript. Tactical Pragmatism: Business and Human Rights in Latin America.
} 
victims. ${ }^{29}$ In its first steps it has added the allegations against corporations complicit in human rights abuses during armed conflict and dictatorships in the world to the CHRDLA cases. Analysis of these cases reveal certain patterns in the capacity of civil society groups to advance judicial and non-judicial accountability mechanisms that address victims' rights to redress and remedy. The project involves developing strategic litigation and non-judicial models of accountability and remedy for adaptation by human rights groups around the world.

The next phase of the CHRD is to conduct statistical analysis of the Latin American cases to finalize the findings from the existing database. In addition, team members are seeking out the significant resources necessary to create a global database, drawing on the BHRRC archive while also supplementing it with additional global and local news sources. Such a project would endeavor to track and make visible claims and responses to corporate human rights claims around the world, to increase victims' access to justice and remedy, and to attach significant social and financial costs to businesses' human rights violations. As such the CHRD could become an important complement to the existing softlaw and voluntary forms of accountability by providing the empirical evidence of compliance with the respect, protect, and remedy norms embodied in the UN Guiding Principles.

\footnotetext{
${ }^{29}$ Payne, Leigh A \& Gabriel Pereira. 2016. "Corporate Complicity in International Human Rights Violations." Annu. Rev. Law Soc. Sci. 12:20.1-20.22
} 


\section{APPENDIX: SECTORS INCLUDED IN THE CHRD-LA}

Agriculture/food/beverage/tobacco/fishing

Apparel and textile

Chemical

Commercial sex and pornography

Conglomerates

Construction and building materials

Consumer products/retail

Finance

Furnishings

Garden/landscaping

Health

Leisure

Manufacturing/machinery

Media/publishing

Metals/plastics/basic materials

Military/weapons/security equipment/restraints

Natural resources

Professional Services

Real estate/property development

Safety devices

Services

Shipping and handling

Sports

Technology

Transport

Travel

Utilities 